\title{
A MODIFICATION OF THE HOLMGREN TEST FOR COLOR BLINDNESS.
}

\author{
By C. M. Westcott, \\ Redlands High School, Redlands, Cal.
}

The prevalence of color blindness among boys, and the importance of the individual being aware of his deficiency in this respect when it exists, seems to warrant our giving rather more attention to the subject than we generally do in the schools.

Having experienced some inconvenience in using the conventional sets of colored yarns in the schoolroom, the writer has devised a modification of the Holmgren test which seems to serve the purpose admirably.

The set of yarns is replaced by a single lantern slide with different portions numbered and colored accurately to the various colors and shades of the test yarns. The method employed is to throw the colors on the screen and ask the members of the class to each make out a list by number of the different shades of the three test colors. An, examination of these lists will betray at a glance anyone deficient in color sense.

The particular advantage of this over the conventional method lies in the fact that the test may be performed on a whole class as easily as on an individual.

\section{NOTE ON THE "NODON VALVE.",}

By WILLIS E. TOWER. Englewood High School, Chicago.

The "Nodon Valve" described in the November, 1907, issue of this journal has brought several letters asking for more information about this useful device.

The original paper upon this apparatus, by Albert Nodon, is to be found in Vol. I of the Proceedings of the International Electrical Congress, St. Louis, 1904, pp. 510-527. The paper describes a series of experiments conducted with a view of determining the most efficient combination of substances for the rectification of alternating currents by electrolytic means. This is found to be a cell containing a saturated solution of ammonium phosphate with electrodes of sheet aluminum and of sheet lead. Sodium and Potassium phosphates may be used, but these liberate 